\title{
A földrajzi köznevek funkcionális jellemzői
}

1. A földrajzi köznevek a helynevekben többféle pozícióban és ezzel (is) összefüggésben többféle szerepkörben állhatnak: könnyü belátni például, hogy a Sáros-patak víznévben és a Sárospatak településnévben a patak földrajzi köznév más-más szerepet tölt be. A víznévben ugyanis a patak funkcionális szerepü egység, vagyis olyan névrész, amely a hely fajtáját jelöli, a helynévi szerep létrehozásában tehát kulcsfontosságú elem. Az ilyen elemeket helynévformánsoknak nevezzük. A településnévben viszont nincs ilyen funkciója a patak lexémának, mivel nem névrész státusban áll; a településnévvé alakulás szempontjából tehát az ilyen elemek nem rendelkeznek az adott helynévben névformáns szereppel. A helynévformáns jelleget mint funkcionális jegyet mindig csak az aktuális névben lehet tehát meghatározni. Írásom témája a földrajzi köznevek e kettős szerepkörének bemutatása, vagyis arra teszek kísérletet, hogy feltárjam a földrajzi köznév (mint lexikális elemcsoport) és a helynévformáns (mint a helynévben elkülöníthető funkcionális egység) kategóriájának a kapcsolatrendszerét. ${ }^{1}$ Ehhez mindenekelőtt a helynévformáns fogalmát kell meghatároznunk, valamint az is szükségesnek látszik, hogy a fó jellemzőit, illetve fajtáit bemutassuk.

A helyneveknek mint tulajdonneveknek a felismerésében - más tulajdonnévfajtákhoz hasonlóan - a jelentésük mellett bizonyos alaki sajátságaik is a segítségünkre lehetnek: az egyes névfajtákon gyakran jelennek meg csak rájuk jellemző lexikális és morfológiai elemek. TÓTH VALÉRIA a helynevek egy fontos csoportjának, a településneveknek a névformánsairól azt tartja, hogy „településnév-formánsnak tekintünk minden olyan morfémát (legyen az földrajzi köznév vagy toldalékmorféma), amely egy adott nyelvben valamely korszakban a településnévi státus nyelvi kifejezésére szolgál, és arra, hogy általa újabb és újabb településneveket hívjunk életre" (2008: 182). Ezt a meghatározást bizonyos módosításokkal a helynévformánsokra általánosabb érvénnyel is kiterjeszthetjük. A helynevek formánsai közé elsősorban a földrajzi közneveket, illetve a képzőket sorolhatjuk (vö. még J. SOLTÉSZ 1979: 20), a névformánsoknak tehát főképpen morfológiai, de részben funkcionális szempontból is kétféle típusát különíthetjük el: a lexikális névformánsokat és a toldalék jellegü, másképpen affixális névformánsokat. Az egyes tulajdonnévfajtáknak (tehát például a helyneveknek vagy a személyneveknek, de ezen belül a különböző hely- és személynévfajtáknak is) saját, csak

*A tanulmány az MTA-DE Magyar Nyelv- és Névtörténeti Kutatócsoport programja keretében, az Emberi Erőforrások Minisztériuma Új Nemzeti Kiválóság Programjának támogatásával készült.

${ }^{1}$ Az adatállomány összeállításához GYÖRFFY GYÖRGY Az Árpád-kori Magyarország történeti földrajza (1963-1998) című munkáját (Gy.), valamint a HoFFMANN IsTVÁN, RÁCZ ANITA és TóTH VALÉRIA által szerkesztett Helynévtörténeti adatok a korai ómagyar korból (HA. 1., 2., 3.; 19972012), illetőleg a Korai magyar helynévszótár (KMHsz. 1., 2005) című munkákat használtam fel. A vizsgálatba ugyancsak bevont jelenkori helynévi adatok a Magyar Nemzeti Helynévtár (MNH.) honlapján közzétett adatbázisból származnak. 
rájuk jellemző névformánsaik lehetnek: a helynevek efféle elemeit nevezzük öszszefoglalóan helynévformánsoknak. Maguk a helynévformánsok is inkább egyes helynévfajtákra lehetnek azonban jellemzőek: beszélhetünk például településnévformánsokról, hegy- és víznévformánsokról stb. A továbbiakban a helynévfajták szokásos rendszerezésének megfelelően főképpen településnév-formánsokról és összefoglalóan a mikrotoponimák formánsairól szólok.

A névformánsok állománya - mint bármely más nyelvi elemcsoporté - nem állandó a nyelvben, hanem időben többé-kevésbé változik. Ebből adódóan egyegy nyelvi elemnek sem általában lehet ilyen szerepe, hanem mindig valamely időszakra vonatkozóan. Mivel azonban ezen a téren a nyelvi változások többnyire meglehetősen lassúak, nyugodtan beszélhetünk egy-egy nagyobb nyelvtörténeti korszak (például az ómagyar kor vagy a mai magyar nyelv) névformánsairól, figyelembe véve természetesen azt is, hogy a nyelv bármely időpillanatában is mutatja a változás képességét és konkrét jeleit. Fontos emellett kiemelnünk, hogy egy adott időszak helynévformánsainak szükségszerüen jellemző sajátsága a termékenység, más szóval produktivitás, vagyis a névformáns jelleget nem pusztán az biztosítja, hogy adott időkeretek között a már meglévő nevekben névformáns szerepet tölt be valamely nyelvi elem, hanem lényeges jellemzője az is, hogy általa újabb és újabb neveket hozhatunk létre (vö. LADÁNYI 2007: 41).

Az alábbiakban nem általában kívánok szólni a helynévformánsokról, hanem annak csupán az egyik típusát, a lexikális helynévformánsokat helyeztem a vizsgálataim középpontjába. Ahogy azt fentebb jeleztem, ebben a funkcióban jellegzetes helyjelölő lexémákat, főként földrajzi közneveket találunk. A továbbiakban azt mutatom be, hogy e két kategória (vagyis a lexikális helynévformánsok és a földrajzi köznevek) milyen viszonyrendszerben állnak egymással, és hogyan értelmezhetjük ezt a kapcsolatot az ómagyar kor vonatkozásában.

2. A földrajzi köznevek speciális helynévalkotó funkciójuknak köszönhetően alkalmasak a lexikális helynévformáns szerep betöltésére. Földrajzi köznevekkel e funkcióban mikrotoponimákban (például Aszó, Nagy-aszó) és településnevekben (például Miklóslaka) egyaránt találkozunk, ugyanakkor a nevekben más, azaz nem névformáns funkcióban is állhatnak (a Nagy-aszó feje név aszó eleme például ebben a névszerkezetben nem névformáns szerepü földrajzi köznév). Általánosítva tehát azt mondhatjuk, hogy a földrajzi köznevek a helynevekben különböző pozíciókban jelentkezhetnek, s ezekben nem feltétlenül azonos funkciót töltenek be: az egyrészes neveket alkotó puszta földrajzi köznévi előfordulások (Aszó) többnyire, a kétrészes nevek utótagjaként álló földrajzi köznevek (Nagy-aszó) pedig minden esetben névformánsként vesznek részt a helynévalkotásban, míg a helynevek elötagjaként vagy annak részeként jelentkező földrajzi köznevek nem névformáns státusúak (Nagy-aszó feje). Nem névformáns szerepü földrajzi köznevek szerepelhetnek lexikálisan összetett, de funkcionálisan egyrészesnek tekintendő nevekben is, ahogyan azt a fentebb említett Sárospatak településnév esete is mutatta.

2.1. A lexikális helynévformánsok körét több okból következően igen nehéz meghatározni. Az ide sorolható lexémák egyfelől nagyon eltérő gyakorisággal fordulnak elő a nevekben, emellett igen gyakran különböző funkcionális gyökerekkel 
bírnak (amíg ugyanis egyesek eleve ilyen szerepűek voltak, mások másodlagosan vették magukra ezt a funkciót), sőt területi-kronológiai különbségek is adódhatnak közöttük. Mindebből következően a lexikális helynévformánsok állományát semmiképpen sem tarthatjuk egyfajta homogén, zárt csoportnak (vö. TóTH 2008: 185).

A lexikális helynévformánsok készletét ennélfogva éppen olyan bizonytalanul tudjuk csak körülhatárolni, mint - más nézőpontból szemlélve - a földrajzi köznevekét. E két szócsoport viszonyrendszerét pedig a következő módon határozhatjuk meg. A földrajzi közneveket elsősorban jelentéstani, illetőleg részben morfológiai alapon definiálhatjuk, előtérbe állítva nyelvbeli funkciójukat, amelyet közszóként a lokális környezet leírásában, illetve a helynevek alkotásában betöltenek. Ilyen értelemben tehát a földrajzi közneveket mint a szókincs egy meghatározott csoportját, mint egy sajátos szemantikai szómező elemeit értelmezzük ahhoz hasonlóan, ahogyan szokás például rokonságnevekről, növénynevekről vagy a mértékegységek neveiröl stb. is beszélni.

A lexikális helynévformánsokat ezzel szemben a helynevekben betöltött szerepük alapján írhatjuk le, s azokat a szavakat soroljuk ide, amelyek a névben a hely fajtájának a megjelölésére szolgálnak. A lexikális helynévformáns tehát olyan viszonyfogalom, amelyet csakis egy-egy névben betöltött szerepe alapján ítélhetünk a helynév ilyen összetevőjének, s ebböl adódóan kizárólag szinkrón síkon értelmezhető. A halom szó például a Hegyes-halom dombnévben névformánsként funkcionál, mivel megjelöli a név denotátumának a fajtáját, a Hegyeshalom településnévben azonban nincs fajtajelölö szerepe, így pedig névformánsnak sem tekinthetjük. E példák is azt mutatják tehát, hogy a földrajzi köznévi jelentéstartalom e szavakat helynévformáns szerepre alkalmassá teszi ugyan, de az, hogy ez a szerep megjelenik-e egy adott földrajzi köznév helynévi alkalmazásában vagy sem, már az illető helynév szerkezetének a függvénye.

Tapasztalataink ugyanakkor azt is mutatják, hogy a helynevekben olyan formánsok is szerepelhetnek, amelyek jelzik ugyan a jelölt hely fajtáját, ám az adott közszónak mint a szókincs elemének valójában nincs a kérdéses helyfajtára utaló földrajzi köznévi jelentése. Ilyenek például az ómagyar korban gyakori háza utótagú településnevek, amelyek egész sor névben megjelennek ([1321]>381>448/15. sz.: Aprohalmhaza, p., Gy. 1: 502; 1357: Benkehaza, KMHsz. 1: 51; 1346: Scemlukhaza, p. Scemlekhaza, p., KMHsz. 255), s utótagjuk egyértelmüen településnév-formánsként funkcionál, anélkül azonban, hogy a ház szónak egyidejüleg - közszói minőségében - az adott korban lett volna 'falu, település' jelentése.

A lexikális helynévformánsoknak ez a kettőssége teszi szükségessé azt, hogy e nyelvi elemkészletet ne homogén csoportként, hanem a maga differenciáltságában láttassuk, azaz elkülönítsünk közöttük elsődleges (primér) és másodlagos (szekundér) lexikális helynévformánsokat. Az elsödleges (primér) és a másodlagos (szekundér) névformáns terminusokat TÓTH VALÉRIA nyomán használom (2008: 185, 186, 192), de minthogy ő ezek fogalmi jelentését a településnevek névformánsaiként határozta meg, az itt tárgyalt általánosabb problematikához igazodva e helyütt némileg kitágítom és átértelmezem ezek szerepkörét.

2.2. Az elsődleges (primér) lexikális helynévformánsok a helynevek azon földrajzi köznévi összetevői, amelyek helyfajtajelölő névrész szerepüket oly mó- 
don töltik be, hogy helynévbeli funkciójuk egybeesik a formánsként álló földrajzi köznév közszói jelentésével (l. erről bővebben BÁBA 2013: 104). A továbbiakban a földrajzi köznevek elsődleges helynévformáns szerepét ómagyar kori példákon mutatom be, szétválasztva a mikrotoponimákban és a településnevekben való megjelenésüket. Vizsgálatom során elsősorban névszerkezeti szempontokat helyeztem előtérbe, de mivel a helynévformáns jelleg megítélése igen gyakran nem választható el a keletkezéstörténeti szempontoktól, a leírásban olykor ez a megközelítés is helyet kapott.

A földrajzi köznevek az ómagyar kori mikrotoponimákban betölthetik a helynévformáns szerepet egyfelöl önmagukban, azaz mindenféle más formáns vagy bővítményrész nélkül állva; például Ér (1229/1550: $E r$, vallem, Gy. 3: 367), Morotva (1212/1397/1405: Mortua, stag., Gy. 1: 328), Sár ([1230]/1231: Sar, rip., Gy. 1: 237). Leginkább azonban kétrészes nevek utótagjaként szerepelnek ebben az időszakban, ez tehát a legjellemzőbb helynévformánsi funkciójuk; például Haraszt-tó (+1252/[1270]: Harozthov, stag., Gy. 2: 565, 607), Nagy-völgy ([1291]/1291: Nogwelg, vall., Gy. 3: 389, 442), Fekete-erdő (1344: Feketeu Erdeu, s., Gy. 2: 564, 637), Hosszú-hegy (1270/272: Huzevheg, mo., Gy. 1: 82). A földrajzi köznevek emellett helynévformánsként egy már meglévő kétrészes mikrotoponimához kapcsolódva újabb helynevet is alkothatnak, mint például a patak a Kút-fó pataka (1249/1321/17. sz.: Kuchfu pataka, fl., Gy. 3: 152, 233) és a határ a Középberek határa (1323: Kezepberekhatara, m., Gy. 2: 586) névben.

Ami a földrajzi közneveknek mint helynévformánsoknak az egyrészes településnevekben betöltött helyzetét illeti, az általam feldolgozott településnévanyagban csak néhány esetben feltételezhetjük valóban földrajzi köznévi névrész, vagyis lexikális helynévformáns meglétét; például ide sorolhatjuk a több helyen is adatolható $L a k$ településneveket ('település Baranya vm. ÉK-i részén Pécsváradtól DK-re', 1296: Loc Lok, v., Gy. 1: 334; 'település Borsod vm. É-i részén a Bódvától K-re', 1222/1550: Loch, v., Gy. 1: 813; 'település Komárom vármegyében', 1332/1378: Laak, p., Gy. 3. 412), illetve a Bodrog megyei Város településnevet (1198 P./PR.: Varos, v., Gy. 1: 732) (vö. BÉNYEI-PETHÖ 1998: 95-6). A valamely földrajzi köznévvel szerkezetileg azonos településnevek között azonban jó néhány olyan is akad (pl. Ér, Hegy), amely nevek nem közvetlenül földrajzi köznevet mint helynévformánst tartalmaznak, hanem egy már korábban is létező helynevet (víznevet, hegynevet). Ez utóbbi típusú településnevek persze az itt vizsgált témakörön kívül rekednek.

A kétrészes településnevek utótagjaként álló földrajzi köznevek ugyancsak valós (és elsődleges) településnév-formánsokként funkcionálnak, azaz a hely fajtájának megjelölésére szolgálnak például az alábbi elnevezésekben: Abafalva 'település Gömör vármegyében, a Sajó bal partján, Gömörtől délre' (1339: Abafalwa, Gy. 2: 480), Ipoltlaka 'település Baranya vármegye keleti részén Mohácstól délre' (1223>1338: Ipolthloka, p., Gy. 1: 302), Újváros 'település Abaúj vármegye keleti részén Szalánctól keletre' (1332-5/PR.: Vyuaros Vyuarus, Gy. 1: 153), Mátéháza 'település Gömör vármegyében, Rimaszombattól délre' (1326: Matheyhaza, Gy. 2: 525). TÓTH VALÉRIA az itt bemutatott értelmezéstől eltérő megközelítést alkalmazva a primér településnév-formánsok közé sorolja ezeken 
kívül az ülés(e) és a szállás(a) lexémát is (2008: 185), ám ezek a korábban megfogalmazottak értelmében másodlagos névformánsnak minősülnek.

2.2.1. Másodlagos helynévformánsoknak tekintem a helynevekben használt olyan fajtajelölő szerepü közszavakat, amelyek valamely névfajta névegyedeinek részeként a gyakori használat következtében tesznek szert a helynévformáns szerepre, a változás azonban nem befolyásolja a formánsként álló nyelvi elem közszói jelentését. A korai ómagyar kori szekundér lexikális településnév-formánsok között kell megemlítenünk néhány, elsődlegesen épületet vagy építményt jelölő lexémát, így például az egyház(a), a monostor(a), a vár(a) és a hid(a) földrajzi közneveket, amelyek egy idő után a helynevekben 'valamilyen építménnyel (templommal, várral stb.) rendelkező falu' jelentést nyertek; az egyház lexéma például TÓTH VALÉRIA szerint eredetileg egészen más jelentéssel bírt, $\mathrm{s}$ csak másodlagosan vette magára a 'templommal bíró falu' jelentést (TóTH 2008: 185-7). Ehhez hasonlóan a valamely más helyhez való viszonyítást kifejező alja lexéma a 'valami alján épült falu' jelentéssel ruházódott fel bizonyos helynevekben (például Egeralja 'égererdő alján települt falu'), a vásár(a) pedig még speciálisabb szemantikai tartalommal a vásártartásra utaló településnevek formánsává vált (például 1324: Boluguasara, v., Gy. 2: 483). A kezdetben 'szolgálattal tartozó emberek csoportja' jelentésủ nép(e) és sok(a) lexémák szintén települések megjelölésére lettek alkalmassá (pl. Ujnép 'újonnan telepített falu', 1352: Wynep, Cs. 2: 654, vö. FNESz. 2: 419; Semjánsoka 'Semján nevü település' vagy 'Semján nevü személyhez tartozó település' [1237-40]: Semyansuka, pr., Gy. 2: 623) (TóTH 2008: 186).

Az egyház(a), hid(a) stb. lexémák névformánssá válásában minden bizonynyal szerepet játszott a névmodellekhez való igazodás tényezője, vagyis a kezdetben valamely azonos szerkezetű mikrotoponimából alakult nevek analógiájára később további névalakulatok jöttek létre, így például az egyház(a) lexéma már meglévő településnevekhez is kapcsolódhatott másodlagosan, s ezáltal jelentése az adott nevekben 'templomos falu'-ra módosult (1. erről bővebben BÁBA 2013: 104-105; vö. még TóTH 2008: 187; MEZÖ 1982: 158, 212-213, 1999: 181, 331).

2.2.2. A mikrotoponimák szekundér helynévformánsai között egy nagyon sajátos, de viszonylag sok elemből álló szócsoportot is találunk, amelyre azért érdemes itt röviden kitérnünk, mert általa jól jellemezhető a másodlagos névformáns funkció kialakulása. Az 'erdő'-t is jelentő fanevek egy csoportjának elemei (jellemzően például a cser, a haraszt és a bükk) ugyanis elsődleges szemantikai tartalmuktól eltávolodva helynévformáns funkciót is magukra vehetnek: a Szurkos-cser erdőnévben a cser például nem 'cserfa' jelentésben szerepel, hanem 'cserfaerdő' jelentéstartalommal bír (1075/+1124/+1217: silvam Huntiensem, que Hungarice Surkuscher vocatur, Gy. 1: 413, 443). A fanevet tartalmazó helynevekben tehát azt figyelhetjük meg, hogy bennük az elsődlegesen 'valamilyen fafajta' jelentésű lexémák nem mindig ezzel a szemantikai értékkel bírnak, alkalmi jelentésmódosulásuk következtében ugyanis speciális helynévformánsként is viselkedhetnek: a haraszt, a cser és a bükk ebben az esetben tehát fajtajelölő szerepet tölt be 'egy bizonyos fajta fából álló erdő' névrészfunkciót kifejezve (1. erről bővebben BÁBA 2012). 
3. Az előzőekben azt láthattuk, hogy a földrajzi köznevek a mikrotoponimákban jellemzően kétrészes nevek utótagjaként állnak helynévformánsként. A földrajzi köznévi lexémák a helynevekben azonban olykor nem helynévformáns szerepben vannak jelen. Itt tehát a két kategória - az előbb felsorolt esetekkel ellentétben - nem esik egybe. A helyet jelölő közszavak ugyanis például a kétrészes helynevek bővítményrészeként is előfordulhatnak, például Szurdok-szád (1288/1302: Zurdukzad, foss., Gy. 1: 315), Szurdok út (1267/1380: Zurdukut, loc., Gy. 1: 369). A szurdok elötagok földrajzi köznévi jellege persze az ilyen jellegü nevekben áttételes (valójában helynévi eredetre visszamenő) is lehet. Helynévformáns szerepről e földrajzi köznevek kapcsán (az efféle mikrotoponimákban) nem beszélhetünk, mivel az adott helynevek helynévként való felismerhetőségüket nem ezeknek az elemeknek, hanem a szád, út utótagjaiknak köszönhetik. Elötagként a földrajzi köznevek az ilyen nevekben mindig sajátosságjelölő szerepet (többnyire lokális utalást) töltenek be.

3.1. Az előtagként álló földrajzi köznevek a korai ómagyar korban különféle funkcióban állhatnak. Elsősorban víznevek körében találkozunk 'az adott helynek/víznek a valamely része' névrészfunkció kifejezésével, például Ág-tö (1268/1347: Agtu, loc., Gy. 3: 387, 458), Ér-tö (1260: Ertu, Gy. 3: 388, 452), Kút-fö (1299/1580 u.: Kwtfw, 1299/1585: Kutfew, Gy. 2: 135), Sziget-fö (1233: Sygethfiu, loc., Gy. 1: 641) (vö. TóTH 2001: 150). Ez a szerepkör megjelenik azonban más helynévfajták esetében is, például Berek-szád ('a berek bejárata, kezdete') (1288: Berukzad, Gy. 2: 207, 288), Szurdok-szád (1288/1302: Zurdukzad, foss., Gy. 1: 315), Áj feje (1255: Ayfey, mo., Gy. 1: 98), Rét-fö (1232>1347: Rethfeu, prat., Gy. 2: 515). Többnyire utak neveiben fordul elő az irány megjelölése, például $B a ́$ nya uta (1324/1326: in viam dictam Banautha, Gy. 3: 236, 264), Bérc uta (1291: berchuta, via Berchwta, Gy. 2: 501), Bérc út (1295/1315: Beerchuth, via, Gy. 2: 530), Szurdok út (1267/1380: Zurdukut, loc., Gy. 1: 369). A hely pontos elhelyezkedésére utalás általában véve is gyakori névrészfunkció (vö. TóTH 2001: 151), s földrajzi köznevek is sürün kifejezik ezt a szerepet, például Megye-ág (megye 'határ') (1272: Megeag, Gy. 2: 615), Megye pataka ([1266]/1266/1274: ubi Megepotoka cadit in aquam Seunche, Gy. 3: 152, 254). Nem tekinthetjük azonban földrajzi köznévnek az egyébként ilyen jelentésben is használt falu névrészt az olyan nevekben, mint a Falu földe (1268/1347: Folufolde, loc., Gy. 3: 447), Falu tava (1307/17. sz.: Falwtova, lac., Gy. 3: 153, 195). Megítélésem szerint az ilyen jellegü nevekben a falu névrész 'faluközösség' jelentéssel bír, azaz nem földrajzi köznévi jelentésében vesz részt a névalkotásban. Ez az értelem nem csupán a helynevekben jelentkezik alkalmi jelentésként, hanem a szó jelentésszerkezetébe szervesen beletartozik (vö. ÉrtSz., TESz. 1: 836), ezért az efféle előfordulásokat nem vehetjük figyelembe a földrajzi köznevek körében.

A földrajzi köznevek föként olyan funkcióban fordulnak elö a helynevek előtagjaként, amely funkciók az előtagokként, első névrészként álló helynevekre is jellemzőek. Ez a párhuzam persze természetes is, hiszen a földrajzi köznevek éppen úgy 'hely' jelentéstartalmat hordoznak magukon, mint a helynevek, csak az előbbiek közszóként, az utóbbiak pedig tulajdonnévi minőségben fejezik ki ezt a szemantikai jegyet. Nem meglepő tehát, ha névrészként is hasonló funkciók betöltésére alkalmasak. 
A földrajzi köznevek állhatnak olyan velük azonos alakú, egyrészes helynevekben is, amelyekben nem fajtajelölő funkciót töltenek be, például 1255/15. sz.: Pogon, fl. (Gy. 1: 776). Nem tekinthetők helynévformánsoknak a földrajzi köznevek az olyan, két lexémából álló egyrészes nevekben sem, mint amilyen a Pásztorrév domb (1238/1296-1301: Pastorreu, coll., Gy. 2: 102, 170), a Halyagrét patak (1291: fl. Holugreth, Gy. 2: 458, 501), az Aphida sziget (1284: Ophida, ins., Gy. 2: 565, 580), illetve a Sóshíd patak (1332: Soushyd, riv., Gy. 3: 326, 380) megnevezése. Az ilyen típusú nevek szerkezeti változás, illetve metonimikus névadás eredményeképpen jöhettek létre, s bennük a névformáns funkció szintén nem érvényesül.

A jelenkori névállományt elemezve feltünik, hogy a földrajzi köznevek olyan nevek második névrészében is állhatnak, mely második névrész szintén kétrészes, földrajzi köznévi utótagú helynév, például Alsó-Kis-liget (MNH. Magyarszék), Kertaljai-Kis-rét (MNH. Juta), Kaposi-Nagy-berek (MNH. Szabadi). A kétrészes nevek lexémáinak számát illetően azonban napjaink névállományában az ómagyar kor névállományához viszonyítva elmozdulás tapasztalható: az ómagyar korban ugyanis a kétrészes nevek döntően két lexémából épültek fel, a mai helynevek között viszont jócskán találunk több lexémából álló neveket is. Mindezt feltehetően a meglévő nevek felhasználásának egyre nagyobb szerepével, illetve a helyek és ezzel együtt a nevek differenciálódásával magyarázhatjuk. Az ómagyar korban kevés példát találunk tehát arra, hogy egy kétrészes név több lexémából épül fel, s ezek között is inkább a két lexémából álló előtag a jellemző, például Hárs-patak-fö (1330: Haaspatokfew, Gy. 1: 85). A Borsod megyei Széles-Hárs-fö név ([1240]: Zelushasfeu, Gy. 1: 810) viszont utótagként tartalmaz kétrészes helynevet, amit az is jelez, hogy szinonim neveként a Hárs-fó név is adatolható ([1240]: Hasfeu, Gy. 1: 810). Természetesen más esetekben is lehet szó arról, hogy az utótag több lexémából áll, ennek igazolását azonban bizonyos körülmények olykor megnehezítik. Talán ide sorolhatunk még néhány, több lexémából álló latinizált forma mögött feltehetően álló magyar nevet is (pl. 1258: Magno Vico Latinorum, Gy. 2: 267, melynek szinonim neveként a Vico Latinorum is adatolható: 1299: Vico Latinorum, Gy. 2: 250, 251, 252, 253), HOFFMANN ISTVÁN szerint ugyanis az oklevelek helyneveire is érvényes az a megállapítás, amelyet BENKŐ LORÁND Anonymusra vonatkozóan fogalmazott meg: ,az anyanyelvi háttér a geszta tulajdonneveinek latin vagy latinosított formáiban is kereshetö, sőt keresendő" (BENKÖ 1996: 224; HOFFMANN 2007: 20). Az ilyen kétrészes nevekben, amelyekben tehát az utótag maga is kétrészes, földrajzi köznévi utótagú helynév, a földrajzi köznevek nem töltenek be névformáns funkciót, mivel csak a másodlagosan létrejött név előzményéül szolgáló névben szolgáltak a helynévi jelleg kifejezésére.

3.2. Földrajzi köznevek a településnevekben is előfordulnak nem névformánsi funkcióban, sőt az egyrészes településneveket alkotó földrajzi köznevek esetében a névformáns funkció jóval ritkábban jelentkezik, mint más (nem névformáns) szerep. A puszta földrajzi köznévvel alakilag azonos településnevek legtöbbje ugyanis metonimikus névadás eredménye. Ilyen településnév például a Morotva Csanád vármegyéből (+1092/+1274//1399: Mortua, pr., v., Gy. 1: 864), melynek közelében a Morotva víznév is adatolható (+1092/+1274//1399: lacu Mortua, Gy. 1: 864), azaz ebben az esetben a Morotva víznév tartalmaz helynévformáns értékü 
földrajzi köznevet, a Morotva településnév pedig már létező helynévből (víznévből) alakult, tehát benne a földrajzi köznévi lexéma nem a településnév, hanem a víznév szempontjából lehet csupán helyfajtajelölő szerepủ helynévformáns.

A földrajzi köznevek az egyrészes, puszta földrajzi köznévi településneveken kívül szerepelhetnek olyan egyrészes, több lexémából álló településnevek névrészeként is, amelyek ugyancsak metonimikusan keletkeztek, például Dobrapataka ('település Gömör vármegyében, a Balog bal partján, Rimaszombattól É-EK-re', 1323>1336: Dubrapotaka, p., Gy. 2: 494), Balogkereke ('település Csanád vm.ben, talán a délkeleti részén', +1256: Bolugkereke, Gy. 1: 847), Bothalma ('település Bodrog vm. nyugati részén Garától keletre', 1290: Budholma, t., Gy. 1: 714). E nevek patak, kerék, halom földrajzi köznevei ugyancsak a településnév előzményéül szolgáló mikrotoponimákban értékelhetők helynévformáns funkcióban álló elemekként. A névegész a településnév szempontjából sajátosságjelölő szerepü, mert azt fejezi ki, hogy a falu a Dobra pataka, Balog kereke stb. nevü hely szomszédságában fekszik.

Mint azt a mikrotoponimák kapcsán már láthattuk, a földrajzi köznevek nem névformáns szerepben állnak az olyan nevekben, ahol a második névrész kétrészes, földrajzi köznévi utótagú helynév. A jelenkori névállományban a településnevek között ide sorolhatjuk többek közt a hivatalos helységnév-változtatást követően víznévi előtaggal kiegészült neveket, például Belényesújlak, Berettyószéplak, Feketeszéplak (MezÖ 1999: 364). Az ómagyar korban ez a névstruktúra nem volt jellemző, de itt idézhető az Abaúj megyei Tökésújfalu településnév (1323/1324/1377: Tenkes huyfalu, p., Gy. 1: 151), amelynek szinonim neveként az előtag nélküli Úffalu is adatolható (1317: v. Vyfolu, Gy. 1: 151).

A fenti példák azt voltak hivatottak illusztrálni, hogy a helynevekben nem minden földrajzi köznévvel azonos elem tekinthető helynévformánsnak, hiszen a földrajzi köznevek a helynevekben nemcsak helyfajtajelölő szerepben állhatnak (ami a leglényegesebb funkciójuk), hanem utalhatnak emellett más, elsősorban lokális viszonyra is. A névformáns funkció értékelésénél ezért a névszerkezetbeli pozícióra is figyelemmel kell lennünk, ez ugyanis alapvetően kijelöli az adott elem lehetséges szerepkörét is.

4. Az alábbiakban azokat az összefüggéseket mutatom be, amelyek a földrajzi közneveket a szókincs más részeihez kapcsolják, kiemelve ebből a körből egyes különösen fontos szócsoportokat, továbbá azokat a viszonyokat, amelyek a földrajzi köznevek és a helynévformánsok kapcsolatát jellemzik. A bonyolult összefüggésrendszer fö elemeinek feltárásával együtt azokra a legfontosabb változásformákra is rá kívánok mutatni, amelyek nyelvünknek ezt a részrendszerét érintik.

4.1. A földrajzi köznév olyan helyjelölö lexéma, amely a helynevek részeként a legtöbb esetben fajtajelölő funkciót tölt be, s ilyen módon egyúttal (elsődleges vagy másodlagos) lexikális helynévformánsként is viselkedik. Abból, hogy a helyfogalmat jelölő lexémák közül valójában csak azokat sorolom a földrajzi köznevek közé, amelyek a helynevekben fajtajelölő szerepet tölthetnek be, az is következik, hogy a földrajzi köznevek fogalmi tartalmának fontos jegyeként tekintem az általuk megjelölt helyfajták tulajdonnévvel való megjelölhetőségét. Az általam vizsgált nyelvi 
kategória „magja”, központi rétege a prototipikus földrajzi köznév, amely primér helynévformáns szerepet tölt be a helynevekben (Újfalu, Nagy-hegy, Rákos-patak).

Adott földrajzi köznév tehát a helynevekben való fajtajelölő funkcióban történő előfordulása által válik prototipikus jellegüvé, mégpedig leginkább annak gyakori használata révén. A jelenség következménye, hogy más, azonos vagy hasonló szerepủ földrajzi köznevek egyúttal visszaszorulnak a nyelvhasználatban, sőt közülük egyesek teljesen ki is esnek a nyelvhasználatból, kihalt szavakká válnak; ilyen földrajzi köznevünk például a jó (1228/1378: Soyou, Gy. 2: 43, 86, 1271: Berukyov, aqua, Gy. 1: 569, 618, 1246/1348/1408: Kethyoukyzi, prat., Gy. 1: 39, 82) (a földrajzi köznévi szerep visszaszorulásáról lásd bővebben BÁBA 2013: 106).

4.2. A korábbiakban jó néhány olyan szekundér helynévformánst is bemutattam, amelyek annak ellenére állnak helynevekben formánsszerepben, hogy mint közszavaknak nincs földrajzi köznévi jelentésük. Ezek között vannak építménynevek (egyház, monostor, vár, ház, híd), fanevek (cser, bükk), embercsoportokat jelölő szavak (népe, soka), de más jelentéskörbe tartozó elemek is. Az ilyen helynévformánsként szereplő szavak funkciójukat tekintve közel állnak a földrajzi köznevekhez, de mégsem azok, mert elsődleges jelentésükben nem szerepel a 'valamilyen típusú hely' értelem.

Szekundér helynévformáns mindezek mellett alakulhat úgy is, hogy az adott elem egy bizonyos szerkezetből válik ki. A szántó lexéma például kezdetben (és még olykor a jelenkori névanyagban is) a szántóföld összetételben (pl. Alsó-szántóföldek, MNH. Komló; Avasi-szántóföld, MNH. Gerényes; Banyik-szántóföld, MNH. Osztopán) melléknévi igenévként fordult elö, később azonban önállóan is betölthette a földrajzi köznévi szerepet (pl. Bakháti-szántó, MNH. Alsómocsolád; Almási-szántók, MNH. Nak; Éger-szántó, MNH. Abaliget stb.). Hasonló jelentésfejlödést tapasztalhatunk a dülö, illetve a jelenkori névanyagban a járó földrajzi köznév kapcsán is, azok ugyanis kezdetben szintén csak melléknévi igenévi jelentésben funkcionáltak, $\mathrm{s}$ csak később önállósultak jelentéstapadással a megfelelő jelzős szerkezetekből (vö. TESz. 1: 697; 1. erről bővebben BÁBA 2013: 107-108).

4.3. A lexikális helynévformánsok állománya olyan értelemben is dinamikus rendszerként müködik, hogy benne elmozdulások, átrendeződések zajlanak le, vagyis az egyes elemek különféle kategóriák között mozoghatnak. Ennek eredményeképpen az elsődleges lexikális helynévformánsként viselkedő földrajzi köznevek bizonyos helynevekben másodlagos helynévformáns szerepet vehetnek magukra.

Az eredetileg 'valakihez tartozó föld, birtok' jelentésü föld(e), telek $\sim$ telke földrajzi köznevek például mikrotoponimákban kezdetben elsődleges lexikális helynévformáns szereppel bírtak (pl. 1279: t-m Diuitis Andree [...] Diues Andreas feldy vocatam, Gy. 1: 221). Minthogy azonban jelentésükből adódóan az ilyen utótagot tartalmazó nevek egy idő után településnévként is funkcionálhattak (pl. Gatafölde 'település Abaúj vármegye déli részén Forrótól délkeletre, a Tarca mellett', 1294: Gothafelde, t., Gy. 1: 85) (TóTH 2008: 185-186), ez lehetőséget teremtett arra, hogy a névhasználók a földe, telke elemekkel közvetlenül is létrehozzanak helységneveket, vagyis ezek a lexémák szekundér helynévformáns szerepet töltsenek be. 
Helyfajták közötti elmozdulást érzékelhetünk a fó helynévformáns kapcsán is, amely kezdetben vízrajzi köznévként ('valaminek a forrása' jelentésben) elsődleges, később azonban 'speciális helyzetü település' jelentésü földrajzi köznévként másodlagos lexikális helynévformánsként funkcionált a helynevekben. A folyónév + fô szerkezetü nevek eredetileg az elötagban álló folyó forrásvidékéről kapták nevüket metonimikus névadás eredményeképpen (pl. Tapolca-fö 'a Tapolca patak forrása' > Tapolcafó 'a Tapolca forrásánál létesült település'). Később, az ilyen típusú nevek hatására elterjedt a víz mellett fekvő települések megjelölésében a fó utótaggal való névalkotás, akár attól is függetlenül, hogy a település a víz forrásától távolabb feküdt, mint ahogyan a Szalafó, Pinkafó és Szuhafó településnevek is keletkeztek a Zala, a Pinka és a Szuha folyónevekböl és a fó utótagból. A fó tehát ezekben a nevekben már településnév-formánsként értékelhető (1. erről bővebben BÁBA 2013: 108-109; vö. még TóTH 2008: 182-187; FNESz.; MEzÖ 1999: 415).

5. A névformánst tartalmazó helynevek tehát többféle forrásból is táplálkozhatnak, többféle történeti folyamat eredményeként jöhetnek létre. Az elsődleges lexikális helynévformánsok állományának alapját a földrajzi köznevek képezik, a másodlagos lexikális helynévformánsok pedig eredetileg nem helyet jelölö, illetve más helyfajtát jelölő szavakból alakulhatnak ki. Ez utóbbi jelenség, vagyis az, hogy az elsődleges és a másodlagos lexikális helynévformánsok között is történhetnek elmozdulások, a rendszer összetettségét és dinamikus voltát még inkább jelzi (1. ehhez az 1. ábrát). Ezzel szoros összefüggésben arról sem szabad megfeledkeznünk azonban, hogy az egyes helynévformánsok idővel a helynévformánsok kategóriájának peremére kerülhetnek, s akár ki is eshetnek a nyelvhasználatból, elveszítve helynévformáns funkciójukat.

1. ábra

A lexikális helynévformánsok rendszere

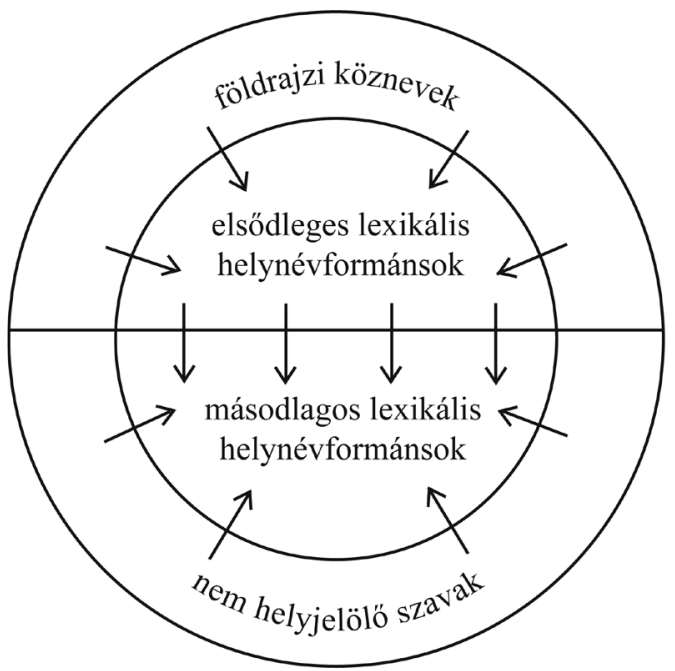


Kulcsszók: fanév, földrajzi köznév, lexikális helynévformáns, településnévformáns, névmodell.

\section{Hivatkozott irodalom}

BÁBA BARBARA 2012. Fanevek helynévformáns szerepe a korai ómagyar korban. Helynévtörténeti Tanulmányok 7: 69-75.

BÁBA BARBARA 2013. Földrajzi köznevek mint lexikális helynévformánsok. Magyar Nyelvjárások 51: 103-110.

BENKÖ LORÁND 1996. Anonymus élő nyelvi forrásai. In: KOVÁCS LÁSZLÓ - VESZPRÉMY LÁsZló szerk., A honfoglaláskor írott forrásai. Balassi Kiadó, Budapest. 221-247.

BÉNYei ÁGNeS - PetHÖ GERGELY 1998. Az Árpád-kori Györ vármegye településneveinek nyelvészeti elemzése. K. n., Debrecen.

Cs. = CsÁNKI Dezsö, Magyarország történelmi földrajza a Hunyadiak korában 1-3., 5. MTA, Budapest, 1890-1913.

ÉrtSz. = A magyar nyelv értelmezö szótára 1-7. Főszerk. BÁRCZI GÉZA - ORSZÁGH LÁszLó. Akadémiai Kiadó, Budapest, 1959-1962.

FNESz. = KISS LAJOS, Földrajzi nevek etimológiai szótára 1-2. Negyedik, bővített és javított kiadás. Akadémiai Kiadó, Budapest, 1988.

Gy. = GYÖRFFY GYÖRGY, Az Árpád-kori Magyarország történeti földrajza 1-4. Akadémiai Kiadó, Budapest, 1963-1998.

HA. 1-3. = HOFFMANN ISTVÁN - RÁCZ ANITA - TÓTH VALÉRIA, Helynévtörténeti adatok a korai ómagyar korból 1-3. K. n. / Debreceni Egyetemi Kiadó, Debrecen, 1997-2012.

HOFFMANN IsTVÁN 2007. A Tihanyi alapitólevél mint helynévtörténeti forrás. Régi magyar helynevek vizsgálatának alapkérdései. Akadémiai doktori értekezés. Kézirat. Debrecen.

KMHsz. = Korai magyar helynévszótár. 1000-1350. 1. Abaúj-Csongrád vármegye. Szerk. HoffMAnN IstVÁN. Debreceni Egyetem Magyar Nyelvtudományi Tanszéke, Debrecen.

LADÁNYI MÁRIA 2007. Produktivitás és analógia a szóképzésben: elvek és esetek. Tinta Könyvkiadó, Budapest.

MEZÖ ANDRÁs 1982. A magyar hivatalos helységnévadás. Akadémiai Kiadó, Budapest.

MEZÖ ANDRÁs 1999. Adatok a magyar hivatalos helységnévadáshoz. Bessenyei György Tanárképző Főiskola Magyar Nyelvészeti Tanszéke, Nyíregyháza.

MNH. = Magyar Nemzeti Helynévtár. http://mnh.unideb.hu

J. Soltész Katalin 1979. A tulajdonnév funkciója és jelentése. Akadémiai Kiadó, Budapest.

TESz. = A magyar nyelv történeti-etimológiai szótára 1-3. Főszerk. BENKŐ LORÁND. Akadémiai Kiadó, Budapest, 1967-1976.

TÓTH VALÉRIA 2001. Névrendszertani vizsgálatok a korai ómagyar korban. Abaúj és Bars vármegye. Debreceni Egyetem Magyar Nyelvtudományi Tanszéke, Debrecen.

TÓTH VALÉRIA 2008. Településnevek változástipológiája. Debreceni Egyetem Magyar Nyelvtudományi Tanszéke, Debrecen. 


\section{Functional properties of geographical common nouns}

Due to their special function in creating toponyms, geographical common nouns (like ocean, hill, or plains) can be seen as a class of lexical formatives of place names. Geographical common nouns can serve this role also in microtoponyms and in names of settlements, but other functions (not name-forming ones) can also be attached to them. Geographical common nouns may occur in various positions in place names; the roles of bare common nouns used as geographical names (in most cases) and those of such nouns occurring as posterior constituents of two-part names typically differ from the roles of geographical common nouns occurring as (parts of) anterior constituents. On the other hand, the inventory of formatives of place names cannot be taken to constitute a homogeneous system, as some of them always had this function whereas others took on this role secondarily: thus we can distinguish primary vs. secondary formatives of place names. This paper presents considerations that link geographical common nouns with other items of the lexicon, with some especially important groups of words treated separately, as well as the relationships between geographical common nouns and formatives of place names in general. Together with an exploration of the major elements of that complex interplay of factors, the most important types of changes that characterise this subsystem of Hungarian are also pointed out.

Keywords: names of trees, geographical common nouns, lexical formatives of place names, formatives of names of settlements, name model.

BÁBA BARBARA

Debreceni Egyetem 